\title{
Characteristics of some co-trimoxazole-resistant Enterobacteriaceae from infected patients
}

\author{
J. BARKER, D. HEALING, AND J. G. P. HUTCHISON \\ From the Regional Public Health Laboratory, East Birmingham Hospital, Birmingham
}

Summary Two isolates of Proteus mirabilis and four of Esch. coli which would not grow on commonly used commercial sensitivity test media are reported. These organisms appear to be resistant to co-trimoxazole, are exacting towards thymidine, and five of six were isolated from patients who had been treated with co-trimoxazole. A method for the detection of these strains is given and their significance in the laboratory and clinical practice discussed.

In the last few months strains of Enterobacteriaceae have been isolated by a method to be described which are exacting towards thymidine and/or other substances and are resistant to co-trimoxazole. The following gives some of the characteristics of six organisms isolated and of their possible significance.

\section{Materials and Methods}

The media used were Oxoid MacConkey agar, Oxoid diagnostic sensitivity test agar (DST), Wellcotest sensitivity agar (WST, Burroughs Wellcome), and Oxoid Columbia base agar. Defibrinated horse blood, lysed with saponin, was added to a final concentration of $5 \%(\mathrm{v} / \mathrm{v})$, where stated in the text. For some months we have been screening all 'coliform' organisms for the failure to grow characteristic on DST lysed horse blood agar. The technique adopted is as follows.

All 'coliform' organisms are grown in $5 \mathrm{ml}$ peptone water for four hours to produce a suspension of faint turbidity. A $10^{-3}$ dilution of this growth is made in non-nutrient medium such as buffered saline or Ringer's solution (1 drop from a 50dropper pipette in $20 \mathrm{ml}$ diluent, or $1,3 \mathrm{~mm}$ loop of culture in $5 \mathrm{ml}$ diluent); this is flooded onto the test plate and the excess fluid quickly sucked off. The test plates are DST agar with $5 \%$ lysed horse blood, and it is essential that light inocula are used (of the order of $10^{3}$ to $10^{5}$ organisms per $\mathrm{ml}, 10^{4}$ organisms being the optimum) which give heavy but not confluent growth. If the inoculum is too heavy 'break through' growth takes place.

SOURCE OF ORGANISMS

Six strains of Enterobacteriaceae have been investiReceived for publication 13 September 1972. gated and their history follows. The number preceding each organism corresponds to its number in Tables I and II.

\section{Proteus mirabilis}

This organism (together with other 'coliforms') was $\vec{\varphi}$ obtained on eight successive occasions from a babp $N$ aged 4 months with a urinary tract infection (recto vesicle fistula). The baby had had several courses of co-trimoxazole (Septrin) between August and December 1971. Two courses lasted three weeks each and one lasted six weeks during which time the organism was repeatedly isolated.

\section{Proteus mirabilis}

This was isolated from the urine of a woman aged 73 with a fractured femur and bronchitis. She had had 13 days' treatment with co-trimoxazole (Septrin) before the organism was isolated.

\section{Escherichia coli, serotype 018 ac. $\mathrm{K}$ ? $\mathrm{H}$ -}

This organism was isolated on three occasions from a woman aged 66 with macrocytic anaemia who developed a urinary tract infection. She had been treated with co-trimoxazole (Septrin) for 13 days before isolation of the organism. (H- means nonmotile serotype.)

4 Escherichia coli, serotype 018 ac. $K$ ? $H$ -

This was isolated on two occasions from a baby of 3 months with a urinary tract infection and an imperforate anus. The child was on co-trimoxazole (Septrin) for 4 months.

5 Escherichia coli, serotype 09. $\mathrm{K} 32 \mathrm{~A}$. $\mathrm{H}$ -

This organism was isolated from a woman aged 55 
with urinary tract infection. Treatment was with co-trimoxazole (Septrin) for 14 days before the organism was isolated.

\section{Escherichia coli, serotype 06. K? HI}

This was isolated from a specimen of pus The patient, aged 4 years, had a spina bifida with an infected meningomyelocele.

This was the only patient of the series who as far as is known had not been treated with co-trimoxazole.

All the above organisms appeared to be resistant to trimethoprim $1.25 \mu \mathrm{g}$ disc, sulphamethoxazole 25 $\mu \mathrm{g}$ disc, and co-trimoxazole $(1.25 \mu \mathrm{g}$ trimethoprim and $23.75 \mu \mathrm{g}$ sulphamethoxazole per disc) when tested on Columbia agar with $5 \%$ horse blood (unlysed). All the organisms appeared to be clinically resistant to co-trimoxazole, for the patients continued to harbour them during treatment, and in three cases a change of treatment to an antibiotic to which the organism was sensitive resulted in its eradication.

After we had submitted this account four more organisms were found with characteristics similar to those already described here, two isolates of $E$. coli (serotypes 083 . K? H4 and $083 \mathrm{~K}$ ? H1), one of Proteus mirabilis, and one of Streptococcus faecalis. The patients from whom these organisms were isolated had all been treated with co-trimoxazole at some time. One further biochemically, similar isolate of $E$. coli (serotype 0 unidentifiable, $\mathrm{H}$-) was sent to us from London by Dr Mair E. M. Thomas.

\section{Findings}

Table I gives a summary of the salient growth characteristics of the six organisms on commercial media. Growth was normal on Oxoid MacConkey and Columbia base (with $5 \%$ unlysed horse blood) media. On Oxoid DST agar only strain 1, Proteus mirabilis, grew normally. On Oxoid DST agar with $5 \%$ lysed horse blood, Wellcotest sensitivity test agar (STA) and Wellcotest STA with $5 \%$ lysed horse blood there was no growth of strains 2 to 6 but strain 1 would grow poorly on DST lysed blood agar.

The reason for failure was examined. The results of supplying various essential metabolites to a thymidine-deficient medium (Wellcotest STA) are summarized in Table II. Para-amino benzoic acid

\begin{tabular}{|c|c|c|c|c|c|c|}
\hline Medium & $\begin{array}{l}\text { I } \\
\text { Proteus } \\
\text { mirabilis }\end{array}$ & $\begin{array}{l}2 \\
\text { Proteus } \\
\text { mirabilis }\end{array}$ & $\stackrel{3}{E}$. coli & $\stackrel{4}{E}$. coli & $\begin{array}{l}5 \\
E . c o\end{array}$ & $\stackrel{6}{E}$. coli \\
\hline $\begin{array}{l}\text { Oxoid MacConkey agar } \\
\text { Oxoid Columbia base }+5 \% \text { unlysed horse blood } \\
\text { Oxoid DST agar } \\
\text { Oxoid DST agar }+5 \% \text { lysed horse blood } \\
\text { Wellcotest sensitivity test agar (STA) } \\
\text { Wellcotest STA }+5 \% \text { lysed horse blood }\end{array}$ & $\begin{array}{l}++ \\
++ \\
++ \\
+ \\
\text { NG } \\
\text { NG }\end{array}$ & $\begin{array}{l}++ \\
++ \\
\text { NG } \\
\text { NG } \\
\text { NG } \\
\text { NG }\end{array}$ & $\begin{array}{l}++ \\
++ \\
\text { NG } \\
\text { NG } \\
\text { NG } \\
\text { NG }\end{array}$ & $\begin{array}{l}++ \\
++ \\
\text { NG } \\
\text { NG } \\
\text { NG } \\
\text { NG }\end{array}$ & $\begin{array}{l}++ \\
++ \\
\pm \\
\text { NG } \\
\text { NG } \\
\text { NG }\end{array}$ & $\begin{array}{l}++ \\
++ \\
\pm \\
\mathbf{N G} \\
\mathbf{N G} \\
\mathbf{N G}\end{array}$ \\
\hline
\end{tabular}

Table I Growth characteristics of the six Enterobacteriaceae on various media

++ numerous large colonies, + numerous small colonies, \pm light growth of tiny colonies. NG no growth.

\begin{tabular}{|c|c|c|c|c|c|c|}
\hline Metabolite & $\begin{array}{l}1 \\
\text { Proteus } \\
\text { mirabilis }\end{array}$ & $\begin{array}{l}2 \\
\text { Proteus } \\
\text { mirabilis }\end{array}$ & $\begin{array}{l}3 \\
\text { E. coli }\end{array}$ & ${ }^{4}$ E. coli & $\begin{array}{l}5 \\
\text { E. coli }\end{array}$ & $\begin{array}{l}6 \\
E \text {. coli }\end{array}$ \\
\hline $\begin{array}{l}\text { PABA } \\
\text { L-glutamic acid } \\
\text { Citrovorum factor } \\
\text { Thymine }\end{array}$ & $\begin{array}{l}\text { NG } \\
\text { NG } \\
\text { NG }\end{array}$ & $\begin{array}{l}\text { NG } \\
\text { NG } \\
\text { NG }\end{array}$ & $\begin{array}{l}\text { NG } \\
\text { NG } \\
\text { NG }\end{array}$ & $\begin{array}{l}\text { NG } \\
\text { NG } \\
\text { NG }\end{array}$ & $\begin{array}{l}\text { NG } \\
\text { NG } \\
\text { NG }\end{array}$ & $\begin{array}{l}\text { NG } \\
\text { NG } \\
\text { NG }\end{array}$ \\
\hline $\begin{array}{l}1000 \mu \mathrm{g} / \mathrm{ml} \\
100 \mu \mathrm{g} / \mathrm{ml} \\
10 \mu \mathrm{g} / \mathrm{ml} \\
\text { Thymidine }\end{array}$ & $\begin{array}{l}\text { NG } \\
\text { NG } \\
\text { NG }\end{array}$ & $\begin{array}{l}\text { NG } \\
\text { NG } \\
\text { NG }\end{array}$ & $\begin{array}{l}++ \\
++ \\
\text { NG }\end{array}$ & $\begin{array}{l}++ \\
\text { NG } \\
\text { NG }\end{array}$ & $\begin{array}{l}++ \\
\text { NG } \\
\text { NG }\end{array}$ & $\begin{array}{l}++ \\
+ \\
\text { NG }\end{array}$ \\
\hline $\begin{array}{l}1000 \mu \mathrm{g} / \mathrm{ml} \\
100 \mu \mathrm{g} / \mathrm{ml} \\
10 \mu \mathrm{g} / \mathrm{ml} \\
1 \mu \mathrm{g} / \mathrm{ml} \\
\text { Deoxy-thymidine-5-monophosphate } 2000 \mu \mathrm{g} / \mathrm{ml} \\
\text { Deoxy-cytidine-5-monophosphate } 1000 \mu \mathrm{g} / \mathrm{ml} \\
100 \mu \mathrm{g} / \mathrm{ml} \\
\text { Deoxy-uridine-5-monophosphate } 1000 \mu \mathrm{g} / \mathrm{ml} \\
100 \mu \mathrm{g} / \mathrm{ml}\end{array}$ & $\begin{array}{l}++ \\
++ \\
+ \\
+ \\
\text { NG } \\
++ \\
+ \\
\text { NG } \\
\pm \\
+ \\
\text { NG }\end{array}$ & $\begin{array}{l}++ \\
++ \\
+ \\
\text { NG } \\
++ \\
\pm \\
\text { NG } \\
\text { NG } \\
\text { NG }\end{array}$ & $\begin{array}{l}++ \\
+ \\
+ \\
\text { NG } \\
++ \\
\text { NG } \\
\text { NG } \\
\text { NG } \\
\text { NG }\end{array}$ & $\begin{array}{l}++ \\
+ \\
\pm \\
\text { NG } \\
++ \\
\text { NG } \\
\text { NG } \\
\text { NG } \\
\text { NG }\end{array}$ & $\begin{array}{l}++ \\
+ \\
\pm \\
\text { NG } \\
++ \\
\text { NG } \\
\text { NG } \\
\text { NG } \\
\text { NG }\end{array}$ & $\begin{array}{l}++ \\
+ \\
\pm \\
\text { NG } \\
++ \\
\text { NG } \\
\text { NG } \\
\text { NG } \\
\text { NG }\end{array}$ \\
\hline
\end{tabular}

Table II Effect of various essential metabolites on the six organisms examined when grown on Wellcotest sensitivity agar

++ numerous large colonies, + numerous small colonies, \pm light growth of tiny colonies, NG no growth. 
(PABA), L-glutamic acid, and the citrovorum factor did not stimulate growth. Thymine $(1000 \mu \mathrm{g} / \mathrm{ml})$ supplied the necessary factor for the $E$. coli strains 3-6 but not for the Proteus strains 1 and 2 (higher concentrations of thymine were also without effect). From Table II it will be seen that some of the $E$. coli (4 and 5) isolates were more exacting to thymine than others. Thymidine provided the necessary metabolite for all six organisms at the same order of concentration, about $10 \mu \mathrm{g} / \mathrm{ml}$. Table II also shows the effect on growth of various other substances on the metabolic pathway.

\section{Discussion}

With one exception the organisms reported were from persons who had had treatment with cotrimoxazole for infections-in five cases of the urinary tract and one of the respiratory tract-and we think that this is a significant fact. The sole exception (case 6) is thought to be a case of ward cross infection. From some of these patients we have evidence of a similar but co-trimoxazolesensitive organism isolated before treatment but there is no certainty that the subsequently resistant organism was derived from it.

There are some points worth stressing: one is that organisms of this sort may be overlooked if not deliberately sought by the method given. Secondly they may fail to grow on sensitivity media and thus give the appearance of having been inhibited by, and therefore very sensitive to, the antibiotics in use. Thirdly it is not easy, even if it is possible, to do sensitivity tests against co-trimoxazole on these organisms, as they have to be supplied with thymidine to grow at all.

Finally, if organisms of the kind reported have indeed developed as a result of exposure to cotrimoxazole then, because of the widespread use of this drug, it is probable that drug-resistant strains will be found with increasing frequency. This view is fortified by the finding of several different $E$. coli serotypes (as well as Proteus and an isolate of Streptococcus faecalis) which indicate that they have changed their characteristics independently and that the isolates are not the result of a single mutant spreading within the hospital. Furthermore we have heard that Dr R. M. Maskell (personal communication) has isolated resistant Proteus strains in Portsmouth, and Dr Mair E. M. Thomas has found an $E$. coli strain in London closely similar biochemically to those we have described here.

We are indebted to Dr Bernard Rowe of the Salmonella and Shigella Reference Laboratory, Colindale, for serotyping the isolates of $E$. coli. 